\title{
ANALISIS POTENSI JENIS POHON LOKAL GUNA REVEGETASI LAHAN TAMBANG EMAS (PT. J-Resources Bolaang Mongondow Site Lanut)
}

\author{
Henratno Pasambuna \\ Jailani Husein \\ Wiske Rotinsulu
}

\begin{abstract}
The purposes of this study are (1) to know the local trees which growing at area before mining operation began and when mining operation by PT. J Resource Bolaang Mongondow has started, (2) to know the kind of local trees which is appropriate with revegetation land, (3) to know technical planning the use of local tree for revegetation gold mine area. This study is use line swath method. This method is as the modification of dual swaths method or track method which with through one or more swaths in the track so that in every line path should have many swaths in some distance. The sampling intensity which use in this study is $10 \%$. The variables (data) of the study are consists by primary data and secondary data. To collect the data the researcher use a literature study which to collect the first data from many literatures about the analysis of local trees and revegetation land, direct observation, and identify kind of local trees by using work sheet data. The result of the study at the PT. J Resources Bolaang Mongondow Lanut-Site forest area, the researcher have found that (1) 29 species of vegetation tree level with the total number 50 individual trees and vegetation of local trees consist of 8 species and those are Matoa (Pometia pinnata), kitchen wood (Dryobalanops aromatic), Gopasa (Vitex cofassus), Sengon (Albazia moluccana), Benuang (Octomeles sumatrana), Trembesi (Albizia saman), Candlenut (Aleurites moluccana), and Durian (Durio spp). From all of the total number of individual trees which is in 6 swaths examples (plot), (2) it has founded 10 species trees level with the level of dominance (level of mastery) in the vegetation community are: Diangow (Anarcadium Sp), Dongiat/Matoa (Pometia Pinnata), Dau'/Dao (Dracontomelon dao), Toraut/Gopasa (Vitex cofassus), Biluk (Aegle marmefes), Nutmeg (Myristica sp), Dongkat/Stone wood (Irvingia malayana oliv), Atul/Kitchen wood (Dryobalanops aromatic), Tagoy (Laportea sinuate), and tula-tula (Floribundus muel). (3) For the revegetation area planning should be formulated that the revegetation area in gold mine must effective and efficient, because the area with slope and difference contour will have different way to handling (land with $<30^{\circ}$ slope have different slope $>30^{\circ}$ ).
\end{abstract}

Keywords: analysis, potentials, local tree, legal revegetation, gold mine, Bolaang Mongondow

\section{ABSTRAK}

Tujuan dari penelitian ini untuk (1) mengetahui jenis-jenis pohon lokal yang tumbuh pada areal sebelum adanya kegiatan penambangan dan pada saat kegiatan penambangan PT. J. Resource Bolaang Mongondow sedang berjalan, (2) mengetahui jenis-jenis pohon lokal yang sesuai untuk kegiatan revegetasi, dan (3) mengetahui rencana teknis pemanfaatan pohon lokal untuk revegetasi lahan tambang emas. Penelitian ini menggunakan metode garis berpetak, metode ini sebagai modifikasi dari metode petak ganda atau metode jalur yaitu dengan cara melompati satu atau lebih petak-petak dalam jalur sehingga sepanjang garis rintis terdapat petak-petak pada jarak tertentu. Intensitas sampling yang digunakan yaitu 10\%. Dalam penelitian ini variabel penelitian (jenis data) yang diamati berupa data primer dan data sekunder. Data-data dikumpulkan dengan cara: studi kepustakaan yaitu pengumpulan data-data dari literatur-literatur tentang analisis potensi jenis pohon lokal dan revegetasi lahan, observasi lapangan, serta identifikasi jenis pohon lokal dengan menggunakan data sheet lapangan. Dari hasil penelitian di kawasan hutan areal PT. J. Resources Bolaang Mongondow Site Lanut, diperoleh (1) data 29 jenis vegetasi tingkat pohon dengan jumlah keseluruhan 50 individu pohon dan vegetasi jenis pohon lokal 8 spesies yaitu Matoa Hutan (Pometia pinnata), Kayu Kapur (Dryobalanops aromatic), Gopasa (Vitex cofassus), Sengon (Albazia falcataria), Benuang (Octomeles sumatrana), Trembesi (Albizia saman), Kemiri (Aleurites moluccana) dan Durian (Durio spp). (2) Dari jumlah keseluruhan individu pohon yang terdapat pada 6 petak contoh (plot), terdapat 10 jenis tingkat pohon dengan tingkat dominasi (tingkat penguasaan) dalam komunitas vegetasi yaitu : Diangow (Anacardium $s p$ ), Dongiat/matoa hutan (Pometia pinnata), Dau'/dao (Dracontomelon dao), Toraut/Gopasa (Vitex cofassus), Biluk (Aegle marmefes), Pala Hutan (Myristica sp), Dongkat/kayu batu (Irvingia malayana Oliv), Atul/kayu kapur (Dryobalanops aromatic), Tagoy (Laportea sinuate), dan Tula-tula (Floribundus muell). (3) Untuk rencana revegetasi lahan dapat dirumuskan bahwa program revegetasi lahan pada tambang emas harus efektif dan efisien karena lahan dengan kemiringan dan kontur yang berbeda akan berbeda pula cara penanganannya (lahan dengan kemiringan $<30^{\circ}$ berbeda dengan kemiringan $>30^{\circ}$ ).

Kata kunci: analisis, potensi, pohon lokal, revegetasi lahan, tambang emas, Bolaang Mongondow 


\section{PENDAHULUAN}

\section{Latar Belakang}

Hutan di Provinsi Sulawesi Utara seluas, 1,88 juta ha yang terdiri dari hutan lindung, hutan produksi tetap, hutan produksi terbatas, hutan produk konversi dan hutan suaka alam. Hasil kehutanan yang dihasilkan adalah jenis kayu besi, meranti, kayu lokal lainnya, rotan, damar, kayu manis, ijuk, daun woka dan lainnya. Potensi pertambangan di Provinsi Sulawesi Utara meliputi tembaga, emas, perak, nikel, titanium, besi, mangan semen, pasir besi/hitam, belerang, kaolin dan bahan galian C seperti pasir, batu, krikil dan trass. Sedangkan untuk persebaran bahan galian $\mathrm{C}$ seperti pasir, batu, krikil dan trass hampir merata diseluruh Sulawesi Utara. Pengelolaan sektor pertambangan di Indonesia, didasarkan pada Pasal 33 ayat (2) dan (3) Undang-Undang Dasar 1945, yang menyatakan bahwa: (1) Cabangcabang produksi yang penting bagi negara dan yang menguasai hajat hidup orang banyak dikuasai oleh negara(2) Bumi dan air dan kekayaan alam yang terkandung di dalamnya dikuasai oleh negara dan dipergunakan sebesarbesarnya untuk kemakmuran rakyat.

Namun yang disayangkan Kegiatan pertambangan terbuka menyebabkan hilangnya keanekaragaman hayati, terjadinya degradasi pada daerah aliran sungai, perubahan bentuk lahan dan terlepasnya logam-logam berat yang dapat masuk ke lingkungan perairan (Rahmawaty, 2002) sehingga perlu dilakukan upaya pemulihan lingkungan melalui reklamasi lahan dan revegetaswi. Upaya reklamasi dan revegetasi di pengusahaan tambang yang masuk dalam Kawasan Budidaya Kehutanan (KBK) mengacu pada aturan yang telah dikeluarkan oleh Kementerian Kehutanan yang mensyaratkan penanaman jenis lokal (Permenhut No. P.4/Menhut-II/2011, Permenhut No. P.60/Menhut-II/2009). Revegetasi dengan tanaman bukan dari jenis pohon lokal akan merubah ekosistem dari kondisinya semula sehingga dikhawatirkan akan menyebabkan hilangnya sebagian jenis tumbuhan maupun hewan. Sementara revegetasi dengan jenis lokal dapat mendukung masuknnya jenis-jenis lain dan cenderung dapat memulihkan lingkungan ekosistem mendekati kondisi aslinya (Rahmawaty, 2002; Ginoga dan
Masripatin, 2009). Jenis pohon lokal khususnya yang memiliki nilai ekonomi tinggi umumnya membutuhkan naungan ketika muda sehingga ketikan ditanam di tempat terbuka akan mati atau pertumbuhannya terhambat (Mansur, 2 2010). Saridan (2009) melaporkan uji coba penanaman jenis meranti dan kapur pada lahan tambang memberikan persen hidup kurang dari $12 \%$, sedangkan hasil penelitian penanaman jenis pionir seperti akasia, gmelina dan waru oleh Iriansyah dan Susilo (2009) menunjukkan persen hidup di atas $79 \%$. Penanaman lahan tambang secara langsung dengan jenis pohon lokal umumnya tidak berhasil dengan baik dibanding dengan introduksi jenis pionir. Informasi jenis-jenis pohon lokal yang dapat digunakan untuk revegetasi lahan tambang Emas belum banyak tersedia. Penelitian untuk melihat potensi jenis-jenis lokal terutama jenis pionir dan cepat tumbuh yang dapat digunakan untuk revegetasi lahan tambang emas perlu dilakukan untuk mendukung keberhasilan reklamasi lahan tambang emas PT. J Resources Bolaang Mongondow merupakan salah satu perusahaan yang bergerak di bidang penambangan emas kabupaten Bolaang Mongondow. Dalam melakukan pengelolaan sumber daya alam diperlukan modal yang sangat besar, peralatan yang canggih, tenaga ahli, dan terdapat pula resiko yang tinggi.

Perseroan Terbatas (PT) J Resources sebagai pelaksana Kontrak Karya tersebut dalam kinerjanya akan diawasi oleh Pemerintah Indonesia selaku salah satu pihak yang terlibat dan bertanggung jawab dalam terlaksananya Kontrak Karya sesuai dengan apa yang tertuang dalam klausula-klausula Kontrak Karya tersebut. Setelah diundangkannya UndangUndang Nomor 22 Tahun 1999 tentang Otonomi Daerah, maka terjadi pelimpahan wewenang di bidang pertambangan yang awalnya dimiliki oleh Pemerintah Pusat, beralih kepada Pemerintah Daerah. Hal tersebut lebih lanjut diatur dalam Peraturan Pemerintah Republik Indonesia Nomor 25 Tahun 2000 tentang Kewenangan Pemerintah dan Kewenangan Propinsi Sebagai Daerah Otonom dalam Pasal 2 ayat (3) angka 3 tentang Bidang Pertambangan danEnergi. Disisi lain program revegetasi hutan dan lahan ini didasarkan pada Peraturan Pemerintah Republik Indonesia No 76 Tahun 2008 tentang Rehabilitasi hutan dan 
lahandimana sangat jelas tertuang pada pasal 1 ayat 3 yaitu Revegetasi adalah usaha untuk memperbaiki dan memulihkan vegetasi yang rusak melalui kegiatan penanaman dan pemeliharaan pada lahanbekas penggunaan kawasan hutan.

\section{Rumusan Masalah}

Berdasarkan uraian latar belakang di atas terdapat beberapa pertanyaan yang berkaitan dengan permasalahan reklamasi lahan tambang emas, yang dapat dirumuskan dalam pertanyaan penelitian sebagai berikut:

1. Identifikasi jenis-jenis pohon lokal apa saja yang dapat tumbuh pada lahan tambang emas?

2. Identifikasi jenis-jenis apa saja yangt sesuai untuk kegiatan revegetasi?

3. Identifikasi kondisi revegetasi lahan tambang emas dengan jenis-jenis pohon lokal?

\section{Tujuan Penelitian}

Penelitian ini bertujuan untuk : (1) Mengidentifikasi jenis-jenis pohon lokal yang tumbuh pada areal sebelum penambangan dan sesudah tambang. (2) Mengidentifikasi jenis-jenis pohon lokal yang sesuai untuk kegiatan Revegetasi. (3) Menganalisa rencana teknis pemanfaatan pohon lokal untuk Revegetasi lahan tambang emas oleh PT. J Resources Bolaang Mongondow.

\section{Manfaat Akademis}

\section{Manfaat Penelitian}

Manfaat teoritis penelitian ini adalah untuk menambah pengetahuan mengenai identifikasi jenis-jenis pohon lokal yang dapat digunakan untuk revegetasi lahan tambang emas khususnya di wilayah Eksploitasi PT. J Resources Bolaang Mongondow

\section{Manfaat Praksis}

Manfaat praksis penelitian ini adalah:

a. Sebagai bahan pertimbangan dalam penyusunan rencana revegetasi lahan tambang emas dengan jenis-jenis pohon lokaloleh PT. J Resources Bolaang Mongondow b. Sebagai masukan bagi pemerintah dalam menentukan kebijakan terkait kegiatan revegetasi lahan tambang emas khususnya Perda tentang lingkungang hidup.

\section{METODOLOGI PENELITIAN}

\section{Tempat dan waktu}

Penelitian ini dilakukan pada Bulan Maret hingga Juni 2015 di areal reklamasi tambang emas pada PT. J. Resources, Desa Lanut Kecamatan Modayag Kabupaten Bolaang Mongondow Timur Sulawesi Utara. Pengumpulan data dilakukan dengan cara Studi Kepustakaan, Observasi dan identifikasi.

\section{Studi Kepustakaan}

Studi kepustakaan dilakukan dalam rangka pengumpulan data dari literature-literatur berupa buku maupun Internet tentang analisis potensi Jenis pohon lokal dan Revegetasi lahan.

\section{Observasi Lapangan}

Kegiatan pengamatan dilapangan meliputi Identifikasi jenis Individu kegiatan Revegetasi lahan oleh PT. J Resources Bolaang Mongondow.

\section{Identifikasi}

Mengidentifikasi jenis pohon lokal guna Revegetasi lahan dengan menggunakan Kuisioner (Data Sheet Lapangan). Adapun data yang diamati dalam penelitian ini adalah berupa data primer dan data sekunder. Pengumpulan data primer dilakukan melalui analisis potensi pada hutan di sekitar areal tambang dan analisis sampel tanah areal hutan dan areal reklamasi. Data sekunder diperoleh melalui studi pustaka terhadap dokumen amdal dan Rencana Penutupan Tambang ( RTP) PT. J- Recources Bolaang Mongondow Site Lanut, peraturan pemerintah yang berlaku, serta hasil-hasil penelitian sebelumnya.

\section{HASIL DAN PEMBAHASAN}

\section{Jenis dan Jumlah Tumbuhan Tingakt pohon}

Setelah mengadakan penelitian dilapangan tentang analisis vegetasi tingkat pohon maka hasil yang diperoleh dapat dilihat pada tabel dibawah ini, jenis dan jumlah tumbuhan tingkat pohon yang ditemukan di areal kawasan PT. J. Resources Bolaang mongondow Site lanut 
kecamatan modayag Kabupaten Bolaang Mongondow Timur.

Tabel 1. Jenis dan Jumlah Tumbuhan Tingkat Pohon

\begin{tabular}{|c|c|c|c|}
\hline No & Nama Botani & Nama Lokal & Jumlah \\
\hline 1 & Pometia pinnata & Doingat (matoa hutan) & 6 \\
\hline 2 & $\begin{array}{l}\text { Dryobalanops } \\
\text { aromatic }\end{array}$ & Atul (Kayu Kapur) & 3 \\
\hline 3 & Aegle marmefes & Biluk & 3 \\
\hline 4 & Anacardium $s p$ & Diangow & 3 \\
\hline 5 & Myristica $s p$ & Pala hutan & 3 \\
\hline 6 & Vitex cofassus & Toraut (Gopasa) & 3 \\
\hline 7 & $\begin{array}{l}\text { Irvingia } \\
\text { malayana }\end{array}$ & Dongkat & 2 \\
\hline 8 & $\begin{array}{l}\text { Floribundus } \\
\text { muell }\end{array}$ & Tula-tula & 2 \\
\hline 9 & Laportea $s p$ & Tagoy & 2 \\
\hline 10 & $\begin{array}{l}\text { Dracontomelon } \\
\text { dao }\end{array}$ & Dauk/dao & 2 \\
\hline 11 & Eugenia & Pakoba & 2 \\
\hline 12 & $\begin{array}{l}\text { Cananga } \\
\text { odorata }\end{array}$ & Amog & 2 \\
\hline 13 & $\begin{array}{l}\text { Zanthoxylum } \\
\text { lymonela (Denst) } \\
\text { Asthon. }\end{array}$ & Taloy/Taroy & 1 \\
\hline 14 & $\begin{array}{l}\text { Celtis } \\
\text { philippinensis }\end{array}$ & Olunan & 1 \\
\hline 15 & $\begin{array}{l}\text { Dacontomelon } \\
\text { dao Merr }\end{array}$ & Loyow & 1 \\
\hline 16 & Cordia obligua & Onunang & 1 \\
\hline 17 & $\begin{array}{l}\text { Albazia } \\
\text { Falcataria }\end{array}$ & Sengon & 1 \\
\hline 18 & $\begin{array}{l}\text { Ficus septicum } \\
\text { Mrm. B }\end{array}$ & Singgolong/ Tagalolo & 1 \\
\hline 19 & Eugenia $s p$ & Gora hutan & 1 \\
\hline 20 & Palaquium sp & Nantu & 1 \\
\hline 21 & $\begin{array}{l}\text { Octomeles } \\
\text { sumatrana }\end{array}$ & Benuang & 1 \\
\hline 22 & Urena lobata $L$ & Pulutan & 1 \\
\hline 23 & Albizia saman & Trembesi & 1 \\
\hline 24 & $\begin{array}{l}\text { Myristica } \\
\text { celebicea }\end{array}$ & Duguan & 1 \\
\hline 25 & $\begin{array}{l}\text { Parinaria } \\
\text { corumbosa }\end{array}$ & Torosik & 1 \\
\hline 26 & $\begin{array}{l}\text { Diospyros } \\
\text { celebica } \text { Bakh }\end{array}$ & Pomosion & 1 \\
\hline 27 & $\begin{array}{l}\text { Aleurites } \\
\text { moluccana }\end{array}$ & Kemiri & 1 \\
\hline 28 & Durio spp & Durian & 1 \\
\hline \multirow[t]{2}{*}{29} & $\begin{array}{l}\text { Koordersiodendr } \\
\text { om pinnatum }\end{array}$ & Kayu bugis & 1 \\
\hline & Jumlah & & 50 \\
\hline
\end{tabular}

Tabel 1 menunjukkan bahwa diperoleh 29 jenis tingkat pohon dengan jumlah keseluruhan 50 individu pohon. Diantara jenis tersebut terdapat 6 individu diantaranya Doingat / Matoa Hutan (pometia pinnata), merupakan jenis pohon dengan jumlah terbanyak pada wilayah petak contoh seluas 1 ha. Tanaman matoa hutan mudah diperkembangbiakan melalui biji dan cara lain seperti cangkok serta okulasi. matoa tumbuh di daerah yang sejuk atau dengan kata lain lebih mudah tumbuh pada ketinggian 900-1700 mdpl, topografi datar atau miring meskipun dapat pula tumbuh di dataran rendah dengan waktu berbunga bulan juli- agustus dan berbuah pada bulan nopember-februari. (Odum, 1971).Sehingga dengan cara tumbuh tersebut dilokasi penelitian merupakan lingkungan yang cocok dengan pertumbuhan matoa hutan.

\section{Kerapatan (K) Tingkat Pohon}

Kerapatan atau Densitas merupakan jumlah individu organisme per satuan ruang atau per unit luas (Indriyanto, 2006). Hasil analisis kerapatan jenis tingkat pohon dapat dilihat pada Tabel 2.

Tabel 2. Kerapatan dan Kerapatan relative Tumbuhan

\begin{tabular}{|c|c|c|c|c|}
\hline \multicolumn{5}{|c|}{ Tingkat Pohon } \\
\hline No & Nama Botani & Nama Lokal & $\mathbf{K}$ & $\begin{array}{l}\text { KR } \\
(\%)\end{array}$ \\
\hline 1 & Pometia pinnata & $\begin{array}{c}\text { Doingat } \\
\text { (matoa hutan) }\end{array}$ & 30 & 12 \\
\hline 2 & Dryobalanops aromatic & $\begin{array}{l}\text { Atul (Kayu } \\
\text { Kapur) }\end{array}$ & 15 & 6 \\
\hline 3 & Aegle marmefes & Biluk & 15 & 6 \\
\hline 4 & Anacardium $s p$ & Diangow & 15 & 6 \\
\hline 5 & Myristica sp. & Pala hutan & 15 & 6 \\
\hline 6 & Vitex cofassus & $\begin{array}{l}\text { Toraut } \\
\text { (Gopasa) }\end{array}$ & 15 & 6 \\
\hline 7 & Irvingia malayana & Dongkat & 10 & 4 \\
\hline 8 & Floribundus muell & Tula-tula & 10 & 4 \\
\hline 9 & Laportea $s p$ & Tagoy & 10 & 4 \\
\hline 10 & Dracontomelon dao & Dauk/dao & 10 & 4 \\
\hline 11 & Eugenia & Pakoba & 10 & 4 \\
\hline 12 & Cananga odorata & Amog & 10 & 4 \\
\hline 13 & $\begin{array}{l}\text { Zanthoxylum lymonela } \\
\text { (Denst) Asthon. }\end{array}$ & Taloy/Taroy & 5 & 2 \\
\hline 14 & Celtis philippinensis & Olunan & 5 & 2 \\
\hline 15 & Dacontomelon dao Merr. & Loyow & 5 & 2 \\
\hline 16 & Cordia obligua & Onunang & 5 & 2 \\
\hline 17 & Albazia Falcataria & Sengon & 5 & 2 \\
\hline 18 & Ficus septicum Mrm. B & $\begin{array}{l}\text { Singgolong/ } \\
\text { Tagalolo }\end{array}$ & 5 & 2 \\
\hline 19 & Eugenia sp. & Gora hutan & 5 & 2 \\
\hline 20 & Palaquium sp. & Nantu & 5 & 2 \\
\hline 21 & Octomeles sumatrana & Benuang & 5 & 2 \\
\hline 22 & Urena lobata $L$. & Pulutan & 5 & 2 \\
\hline 23 & Albizia saman & Trembesi & 5 & 2 \\
\hline 24 & Myristica celebicea & Duguan & 5 & 2 \\
\hline 25 & Parinaria corumbosa & Torosik & 5 & 2 \\
\hline 26 & Diospyros celebica Bakh & Pomosion & 5 & 2 \\
\hline 27 & Aleurites moluccana & Kemiri & 5 & 2 \\
\hline 28 & Durio spp & Durian & 5 & 2 \\
\hline 29 & $\begin{array}{l}\text { Koordersiodendrom } \\
\text { pinnatum }\end{array}$ & Kayu bugis & 5 & 2 \\
\hline & Jumlah & & 250 & 100 \\
\hline
\end{tabular}

Tabel 2 menunjukkan bahwa jenis tingkat pohon Doingat / matoa hutan, yang memiliki tingkat Kerapatan Relatif (KR) tertinggi yaitu 12 $\%$. Jenis kayu Atul / Kayu kapur, Biluk, Diangow, Pala hutan, Toraut / Gopasa, merupakan jenis kayu tertinggi kedua dengan masing-masing Kerapatan Relatif (KR) $6 \%$. Kemudian Jenis Dongkat, Pakoba, Tula-tula, Tagoy, Dauk, Amok dengan masing-masing Kerapatan Ralatif (KR) 4\%.Dan 17 jenis pohon lainya dengan tingkat Kerapatan Relatif (KR) terendah yaitu $2 \%$. 


\section{Frekuensi (F) Tingkat Pohon}

Frekuensi dipergunakan untuk menyatakan proporsi antara jumlah sampel yang berisi suatu jenis tertentu terhadap jumlah sampel. Frekuensi jenis tumbuhan adalah jumlah petak contoh tempat ditemukannya suatu jenis dari sejumlah petak contoh yang dibuat (Indriyanto, 2006). Hasil analisis frekuensi tumbuhan tingkat pohon dapat dilihat pada Tabel 3 .

Tabel 3. Frekuensi dan Frekuensi Relatif Tumbuhan Tingkat Pohon

\begin{tabular}{|c|c|c|c|c|}
\hline No & Nama Botani & Nama Lokal & $\mathbf{F}$ & $\begin{array}{r}\text { FR } \\
(\%)\end{array}$ \\
\hline 1 & Pometia pinnata & $\begin{array}{c}\text { Doingat } \\
\text { (matoa hutan) }\end{array}$ & 0,6 & 7,5 \\
\hline 2 & Dryobalanops aromatic & $\begin{array}{l}\text { Atul (Kayu } \\
\text { Kapur) }\end{array}$ & 0,2 & 2,5 \\
\hline 3 & Aegle marmefes & Biluk & 0,6 & 7,5 \\
\hline 4 & Anacardium sp & Diangow & 0,4 & 5 \\
\hline 5 & Myristica sp. & Pala hutan & 0,4 & 5 \\
\hline 6 & Vitex cofassus & $\begin{array}{l}\text { Toraut } \\
\text { (Gopasa) }\end{array}$ & 0,6 & 7,5 \\
\hline 7 & Irvingia malayana & Dongkat & 0,4 & 5 \\
\hline 8 & Floribundus muell & Tula-tula & 0,4 & 5 \\
\hline 9 & Laportea sp & Tagoy & 0,4 & 5 \\
\hline 10 & Dracontomelon dao & Dauk/dao & 0,2 & 2,5 \\
\hline 11 & Eugenia & Pakoba & 0,2 & 2,5 \\
\hline 12 & Cananga odorata & Amog & 0,2 & 2,5 \\
\hline 13 & $\begin{array}{l}\text { Zanthoxylum lymonela } \\
\text { (Denst) Asthon. }\end{array}$ & Taloy/Taroy & 0,2 & 2,5 \\
\hline 14 & Celtis philippinensis & Olunan & 0,2 & 2,5 \\
\hline 15 & $\begin{array}{l}\text { Dacontomelon dao } \\
\text { Merr. }\end{array}$ & Loyow & 0,2 & 2,5 \\
\hline 16 & Cordia obligua & Onunang & 0,2 & 2,5 \\
\hline 17 & Albazia Falcataria & Sengon & 0,2 & 2,5 \\
\hline 18 & Ficus septicum Mrm. B & $\begin{array}{l}\text { Singgolong/ } \\
\text { Tagalolo }\end{array}$ & 0,2 & 2,5 \\
\hline 19 & Eugenia sp. & Gora hutan & 0,2 & 2,5 \\
\hline 20 & Palaquium sp. & Nantu & 0,2 & 2,5 \\
\hline 21 & Octomeles sumatrana & Benuang & 0,2 & 2,5 \\
\hline 22 & Urena lobata $L$. & Pulutan & 0,2 & 2,5 \\
\hline 23 & Albizia saman & Trembesi & 0,2 & 2,5 \\
\hline 24 & Myristica celebicea & Duguan & 0,2 & 2,5 \\
\hline 25 & Parinaria corumbosa & Torosik & 0,2 & 2,5 \\
\hline 26 & $\begin{array}{l}\text { Diospyros celebica } \\
\text { Bakh }\end{array}$ & Pomosion & 0,2 & 2,5 \\
\hline 27 & Aleurites moluccana & Kemiri & 0,2 & 2,5 \\
\hline 28 & Durio spp & Durian & 0,2 & 2,5 \\
\hline 29 & $\begin{array}{l}\text { Koordersiodendrom } \\
\text { pinnatum }\end{array}$ & Kayu bugis & 0,2 & 2,5 \\
\hline \multicolumn{3}{|c|}{ Jumlah } & 8,0 & 100 \\
\hline
\end{tabular}

Tabel 3 menunjukkan bahwa tingkat Frekuensi Relatif (FR) tertinggi yaitu 7,5\% dimiliki jenis pohon Doingat/matoa hutan, Biluk, Toraut/Gopasa. Jenis Diangow, Pala Hutan, Dongkat, Tula-tula, Tagoy, memiliki tingkat Frekuensi Relatif (FR) kedua dengan masing-masing 5\%. Dan 21 jenis pohon lainnya dengan tingkat Frekuensi Relatif (FR) terendah yaitu 2,5\%. Pada pengamatan ini frekuensimerupakan besarnya intensitas ditemukannnya organisme dalam komunitas atau ekosistem. Makin banyak petak contoh yang didalamnya ditemukan suatu jenis, berarti makin besar frekuensi jenis tersebut. Dengan demikian tabel frekuensi diatas menggambarkan tingkat penyebaran jenis dikelompok hutan Desa Lanut dalam areal kawasan PT. J. Resources Bolaang mongondow timur.

\section{Dominasi (D) Tingkat Pohon}

Dominansi adalah istilah yang digunakan untuk menyatakan luas penutupan suatu jenis tersebut.Luas penutupan dapat dinyatakan dengan menggunakan luas penutupan tajuk atau Luas Bidang Dasar (LBD). Parameter tersebut merupakan bagian dari parameter yang digunakan untuk menunjukan jenis tumbuhan yang dominan dalam suatu ekosistem (Irdriyanto, 2006).Hasil Dominansi dan Dominansi Relatifdapat dilihat pada Tabel 4.

Tabel 4. Dominasi dan Dominasi Relatif Tumbuhan Tingkat Pohon

\begin{tabular}{|c|c|c|c|c|}
\hline No & Nama Botani & Nama Lokal & D & $\begin{array}{l}\text { DR } \\
(\%)\end{array}$ \\
\hline 1 & Pometia pinnata & $\begin{array}{c}\text { Doingat } \\
\text { (matoa hutan) }\end{array}$ & 2,73 & 7,31 \\
\hline 2 & $\begin{array}{l}\text { Dryobalanops } \\
\text { aromatic }\end{array}$ & $\begin{array}{l}\text { Atul (Kayu } \\
\text { Kapur) }\end{array}$ & 1,5305 & 4,10 \\
\hline 3 & Aegle marmefes & Biluk & 1,465 & 3,92 \\
\hline 4 & Anacardium sp & Diangow & 7,748 & 20,76 \\
\hline 5 & Myristica sp. & Pala hutan & 1,749 & 4,68 \\
\hline 6 & Vitex cofassus & $\begin{array}{l}\text { Toraut } \\
\text { (Gopasa) }\end{array}$ & 2,395 & 6,41 \\
\hline 7 & Irvingia malayana & Dongkat & 3,8865 & 10,41 \\
\hline 8 & Floribundus muell & Tula-tula & 0,4525 & 1,21 \\
\hline 9 & Laportea sp & Tagoy & 0,7535 & 2,01 \\
\hline 10 & Dracontomelon dao & Dauk/dao & 5,1575 & 13,81 \\
\hline 11 & Eugenia & Pakoba & 0,5425 & 1,45 \\
\hline 12 & Cananga odorata & Amog & 0,4015 & 1,07 \\
\hline 13 & $\begin{array}{l}\text { Zanthoxylum } \\
\text { lymonela (Denst) } \\
\text { Asthon. }\end{array}$ & Taloy/Taroy & 0,4805 & 1,28 \\
\hline 14 & Celtis philippinensis & Olunan & 0,628 & 1,68 \\
\hline 15 & $\begin{array}{l}\text { Dacontomelon dao } \\
\text { Merr. }\end{array}$ & Loyow & 0,537 & 1,44 \\
\hline 16 & Cordia obligua & Onunang & 0,5085 & 1,36 \\
\hline 17 & Albazia Falcataria & Sengon & 0,537 & 1,44 \\
\hline 18 & $\begin{array}{l}\text { Ficus septicum Mrm. } \\
B\end{array}$ & $\begin{array}{l}\text { Singgolong/ } \\
\text { Tagalolo }\end{array}$ & 0,226 & 0,60 \\
\hline 19 & Eugeniasp. & Gora hutan & 0,2075 & 0,56 \\
\hline 20 & Palaquium sp. & Nantu & 1,1205 & 3,00 \\
\hline 21 & $\begin{array}{l}\text { Octomeles } \\
\text { sumatrana }\end{array}$ & Benuang & 0,8305 & 2,22 \\
\hline 22 & Urena lobata $L$. & Pulutan & 0,266 & 0,60 \\
\hline 23 & Albizia saman & Trembesi & 0,377 & 0,01 \\
\hline 24 & Myristica celebicea & Duguan & 0,1895 & 0,51 \\
\hline 25 & $\begin{array}{l}\text { Parinaria } \\
\text { corumbosa }\end{array}$ & Torosik & 0,265 & 0,71 \\
\hline 26 & $\begin{array}{l}\text { Diospyros celebica } \\
\text { Bakh }\end{array}$ & Pomosion & 1,32 & 3,53 \\
\hline 27 & Aleurites moluccana & Kemiri & 0,353 & 0,94 \\
\hline 28 & Durio spp & Durian & 0,377 & 0,01 \\
\hline 29 & $\begin{array}{l}\text { Koordersiodendrom } \\
\text { pinnatum }\end{array}$ & Kayu bugis & 0,3075 & 0,82 \\
\hline \multicolumn{3}{|c|}{ Jumlah } & 37,32 & $\mathbf{9 8 , 8 5}$ \\
\hline
\end{tabular}


Tabel 4 menunjukkan bahwa beberapa jenis tingkat pohon yang memiliki tingkat Dominansi Relatif (DR) tertinggi diantaranya yaitu jenis Diangow,20,76 \%. Dauk dan Dongkat yang mempunyai Dominansi Relatif (DR) masing-masing $13,81 \%$ dan 10,41\%. Serta jenis Toraut dan Doingat dengan Dominansi Relatif (DR) masing-masing $6,41 \%$ dan $7,31 \%$.

\section{Indeks Nilai Penting (INP) Tingkat Pohon} Indeks Nilai Penting (INP) adalah parameter kuantitatif yang dipakai untuk menyatakan tingkat dominansi (tingkat penguasaan) jenis-jenis dalam suatu komunitas tumbuhan. Jenisjenis yang dominan dalam suatu komunitas tumbuhan akan memiliki Indeks Nilai Penting (INP) yang tinggi, sehingga jenis-jenis yang paling dominan tentu saja meiliki indeks nilai penting yang paling besar( Indriyanto, 2006). Di bawah ini adalah tabel indeks nilai penting hasil analisis data dilapangan dapat dilihat pada Tabel 5 .

\begin{tabular}{|c|c|c|c|}
\hline No & Nama Botani & Nama Lokal & $\begin{array}{l}\text { INP } \\
(\%)\end{array}$ \\
\hline 1 & Pometia pinnata & $\begin{array}{c}\text { Doingat } \\
\text { (matoa hutan) }\end{array}$ & 26,81 \\
\hline 2 & $\begin{array}{l}\text { Dryobalanops } \\
\text { aromatic }\end{array}$ & $\begin{array}{l}\text { Atul (Kayu } \\
\text { Kapur) }\end{array}$ & 12,6 \\
\hline 3 & Aegle marmefes & Biluk & 17,42 \\
\hline 4 & Anacardium $s p$ & Diangow & 31,76 \\
\hline 5 & Myristica sp. & Pala hutan & 15,68 \\
\hline 6 & Vitex cofassus & Toraut (Gopasa) & 19,91 \\
\hline 7 & Irvingia malayana & Dongkat & 14,91 \\
\hline 8 & Floribundus muell & Tula-tula & 10,21 \\
\hline 9 & Laportea sp & Tagoy & 11,01 \\
\hline 10 & Dracontomelon dao & Dauk/dao & 22,81 \\
\hline 11 & Eugenia & Pakoba & 7,95 \\
\hline 12 & Cananga odorata & Amog & 5,57 \\
\hline 13 & $\begin{array}{l}\text { Zanthoxylum lymonela } \\
\text { (Denst) Asthon. }\end{array}$ & Taloy/Taroy & 5,78 \\
\hline 14 & Celtis philippinensis & Olunan & 6,18 \\
\hline 15 & $\begin{array}{l}\text { Dacontomelon dao } \\
\text { Merr. }\end{array}$ & Loyow & 0,94 \\
\hline 16 & Cordia obligua & Onunang & 5,86 \\
\hline 17 & Albazia Falcataria & Sengon & 5,94 \\
\hline 18 & Ficus septicum Mrm. B & $\begin{array}{l}\text { Singgolong/Taga } \\
\text { lolo }\end{array}$ & 5,1 \\
\hline 19 & Eugenia sp. & Gora hutan & 5,06 \\
\hline 20 & Palaquium sp. & Nantu & 7,5 \\
\hline 21 & Octomeles sumatrana & Benuang & 6,72 \\
\hline 22 & Urena lobata $L$. & Pulutan & 5,1 \\
\hline 23 & Albizia saman & Trembesi & 4,51 \\
\hline 24 & Myristica celebicea & Duguan & 5,01 \\
\hline 25 & Parinaria corumbosa & Torosik & 5,21 \\
\hline 26 & $\begin{array}{l}\text { Diospyros celebica } \\
\text { Bakh }\end{array}$ & Pomosion & 8,03 \\
\hline 27 & Aleurites moluccana & Kemiri & 5,44 \\
\hline 28 & Durio spp & Durian & 4,51 \\
\hline 29 & $\begin{array}{l}\text { Koordersiodendrom } \\
\text { pinnatum }\end{array}$ & Kayu bugis & 5,32 \\
\hline \multicolumn{3}{|c|}{ Jumlah } & 298,85 \\
\hline
\end{tabular}

Tabel 5 menunjukkan bahwa indeks nilai penting diatas dapat dilihat gambaran jenis tingkat pohon yang dominan (yang berkuasa) pada Kawasan Hutan di areal kawasan PT. J. Resources Bolaang mongondow Site lanut kecamatan modayag Kabupaten Bolaang Mongondow Timur. Jenis-jenis yang dominan diantaranya Diangow dengan nilai INP 31,76 $\%$, Doingat / matoa hutan dengan INP 26,81, Dauk dengan nilai INP $22,81 \%$, Toraut / Gopasa dengan INP 19,91\%, Biluk dengan nilai INP 17,42 \%, Pala Hutan dengan nilai INP $15,68 \%$, Dongkat dengan nilai INP 14,91\%, dan Atul/Kayu kapur dengan Nilai INP 12,6\%. Serta jenis tagoy dan tula-tula memiliki nilai INP masing-masing $11,01 \%$ dan 10,21\%.

\section{KESIMPULAN DAN SARAN}

\section{Kesimpulan}

Dari hasil penelitian diatas dapat diperoleh data 29 jenis vegetasi tingkat pohon dengan vegetasi jenis pohon lokal 8 spesies jenis yaitu Matoa Hutan (Pometia pinnata), Kayu Kapur (Dryobalanops aromatic), Gopasa (Vitex cofassus), Sengon (Albazia Falcataria), Benuang (Octomeles sumatrana), Trembesi (Albizia saman), Kemiri (Aleurites moluccana), dan Durian (Durio spp). Pada Kawasan Hutan Di areal kawasan PT. J. Resources Bolaang mongondow site Lanud Kabupaten Bolaang mongondow timur diperoleh 29 jenis fase pohon, dengan jumlah keseluruhan 50 individu pohon yang terdapat pada 6 petak contoh (plot). Terdapat 10 jenis tingkat pohon dengan tingkat dominansi (tingkat penguasaan) dalam komunitas Vegetasi di dalam areal kawasan PT. J. Resources Bolaang mongondow timur yaitu : Diangow (Anacardium sp), Doingat/matoa hutan (Pometia pinnata), Dau'/dao (Dracontomelon dao), Toraut/Gopasa (Vitex cofassus), Biluk (Aegle marmefes), Pala Hutan (Myristica sp), Dongkat/kayu batu (Irvingia malayana Oliv), Atul/kayu kapur (Dryobalanops aromatic), Tagoy (Laportea sinuate) dan Tula-tula (Floribundus muell) yang memiliki Indeks Nilai Penting (INP) $>10 \%$. Pada rencana teknis revegetasi lahan dapat dirumuskan bahwa program revegetasi lahan pada tambang emas harus dilakukan dengan cara yang efektif dan efisien dikarenakan pada 
lahan dengan kemiringan dan kontur yang berbeda akan berbeda juga cara penangganannya. Sehingga lahan pada kemiringan $<30^{\circ}$ dan lahan pada kemiringan $>30^{\circ}$ akan berbeda pada proses realisasi program.

\section{Saran}

Untuk mendapatkan data dan informasi yang akurat serta dapat dijadikan sebagai acuan bagi penelitian selanjutnya, perlu adanya aspekaspek atau faktor-faktor yang bisa dijadikan takaran bagi keberhasilan revegetasi lahan di kawasan pertambangan, serta adanya rencana awal revegetasi baik sebelum atau sesudah tambang (close mainning). Dan perlu adanya panduan standar operasional terkait proses revegetasi lahan tambang baik itu kondisi lahan, faktor iklim dan faktor vegetasi yang baik untuk pelaksanaan revegetasi atau rehabilitasi lahan pertambangan. Serta menjadi bahan masukan bagi seluruh stakeholder khususnya pemerintah Kabupaten Bolaang Mongondow Timur guna penanganan lahan/area kawasan pasca tambang baik pengelolaan itu serta ekologis, ekonomis maupun secara ekosistem.

\section{DAFTAR PUSTAKA}

Atlas Kayu Indonesia, 2005: Jilid I. Departemen Kehutanan. Badan Penelitian Pengembangan Kehutanan.

Arrijani, 2000. Taksonomi Tumbuhan. Jurusan Pendidikan Biologi FPMIPA IKIP Manado.

Badan Planologi Departemen Kehutanan, data s/d Januari 2007. (Planning Agency Department of Forestry Data of January 2007) Source.

Davis dan Jhonson, 1987. Forest Management. Mc Graw-Hill Book Company. Newyork.

Dinas Pertambangan dan Energi Kabupaten Bolaang Mongondow Timur 2014

Dinas Kehutanan dan Perkebunan Kabupaten Bolaang Mongondow Timur 2014
Greig, 1983. Quantitative Plant Ecology, Blackwell Scientific Publications, Oxford.

Indriyanto, 2005. Dendrologi. Penerbit Universitas Lampung. Bandar Lampung.

Indriyanto, 2006. Ekologi Hutan. PT. Bumi Aksara: Jakarta.

Jurnal Pasir Laut. Vol.3 No.1 : 27-45, 2007

Kartaminata, K. dan Danimiharja. 1992, Jakarta: Yayasan Obor Indonesia.

Keputusan Menteri Kehutanan No 70/KPTSII/2000

Kusmana. C. 1997. Ekologi dan sumber daya ekosistem mangrove.Bogor : Jurusan Manajement Hutan Fakultas Kehutanan IPB

Latifah, 2004. dalam Pertumbuhan Dan Hasil Tegakan Eucalyptus grandis DI Hutan Tanaman Industri. ITI Jurusan Kehutanan Fakultas Pertanian Universitas Sumatera Utara.

Mueler-Dumbois \& Ellenberg, 1974. Aims and Methods of Vegetation ecology. Jhon Willey and Sons, New York.

Odum, 1993. Dasar - dasar Ekologi. UGM Press. Yogyakarta.

Odum, 1996. Dasar-Dasar Ekologi. Ir. Tjahyono Samingan, MSc. Gadjah Mada University Press. Yogyakarta.

Onrizal, 2008. http://onrizal.files.wordpress. com /2008/10/kul-1-5.pdf

Odum, Eugene. 1971. Dasar-dasar Ekologi. Gadjah mada University press.Yogyakarta.

Permenhut No. P.4/Menhut-II/2011, Permenhut No. P.60/Menhut-II/2009 
Peterson, 2003. Hydrophilic polymers - effects and uses in the landscape.

Purborini, 2006.Struktur dan Komposisi Tumbuhan, Semarang.

Resosoedarmo dkk, 1984. Pengantar Ekologi. Bandung: CV. Remaja Karya.

Rusmendro, 2007. Nilai Penting sebagai Indikator Kedudukan Jenis Dalam Komunitas Tumbuhan. Jakarta.

Simon, 2004. Merencanakan Pembangunan Hutan untuk Strategi Kehutanan Sosial, Yayasan Pusat Studi Sumber Daya Hutan.

Soerianegara, 1996. dalam Ekologi, Ekologisme dan Pengelolaan Sumber daya Hutan. Jurusan Manajemen Hutan Fakultas Kehutanan, Institut Pertanian Bogor.Bogor.

Supriatno, 2001. dalam Pengantar Praktek Ekologi Tumbuhan. Bandung: Jurusan Pendidikan Biologi FMIPA Universitas Pendidikan Indonesia.

Soegianto, 2009. Analisis vegetasi. http:bpkaeknauli.org/indeks.php?option $=5$ diakses pada 8 november 2015 .

Syamsuri, 2000. dalam Biologi 2000, SMA kelas 2A. Erlangga. Jakarta.
Umar, R. 2013. Penuntun Praktikum Ekologi Umum. Jurusan Biologi, Universitas Hasanuddin, Makasar.

Wibowo, H. 2002. Analisis Struktur dan Komposisi tegakan Hutan Alam tanah kering bekas tebangan study kasus dipetak RIL.

Whittaker, 1975. dalam Communities and Ecosystem. 2nd. Macmillan Publishing Co.Inc.New York.

William clowes and sons, 1973. Quantitative and Dinamic Plant Ecology. Second Edition. London.

http://www.hort.agri.umn.edu/ h5015/peterson.htm, Diakses 5 Februari 2015.

http://adnalestary.blogspot.com/2011/12/komun itas-tumbuhan.html

http://www.irwantoshut.net/analisis_vegetasi_p arameter_kuantitatif.html 